\title{
Knowledge sharing behaviour among non-academic staff in higher learning institutes: The role of trust and perceived risk
}

\author{
Muhammad Sabbir Rahman \\ North South University (NSU), Bangladesh \\ Nuraihan Mat Daud \\ International Islamic University Malaysia (IIUM), Malaysia \\ Murali Raman \\ Multimedia University (MMU), Malaysia
}

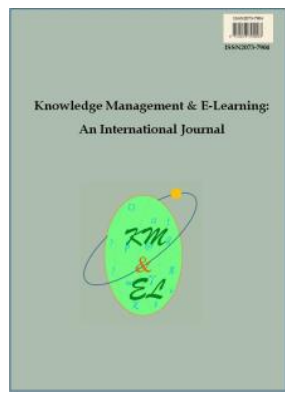

Knowledge Management \& E-Learning: An International Journal (KM\&EL) ISSN 2073-7904

\section{Recommended citation:}

Rahman, M. S., Daud, N. M., \& Raman, M. (2018). Knowledge sharing behaviour among non-academic staff in higher learning institutes: The role of trust and perceived risk. Knowledge Management \& E-Learning, 10(1), $113-124$. 


\title{
Knowledge sharing behaviour among non-academic staff in higher learning institutes: The role of trust and perceived risk
}

\author{
Muhammad Sabbir Rahman* \\ Department of Marketing and International Business \\ North South University (NSU), Bangladesh \\ E-mail: sabbiriiu@gmail.com
}

\section{Nuraihan Mat Daud}

Faculty of Languages and Management International Islamic University Malaysia (IIUM), Malaysia

E-mail: nuraihan@iium.edu.my

\section{Murali Raman}

Faculty of Management

Multimedia University (MMU), Malaysia

E-mail: murali.raman@mmu.edu.my

*Corresponding author

\begin{abstract}
The purpose of the paper is to analyse knowledge sharing behaviour among non-academic staff of higher learning institutions. This research focuses on the mediation impact of perceived risk on trust and knowledge sharing behaviour. The research also proposes actions that can be taken by higher learning institutions to enhance trust among the staff in order to create a knowledge sharing environment at the workplace. This research applied confirmatory factor analysis and Structural Equation Modeling (SEM) to evaluate the proposed measurement model and proved the research hypotheses. The findings from the research show that perceived risk plays a strong mediating role between trust and knowledge sharing behaviour among the nonacademic staff of higher learning institutions. The SEM analysis also confirmed that the research model shows a good fit. This research highlights issues concerning knowledge sharing practices among non-academic staff and provides some recommendations to the managers to address these issues. The researchers agreed that more research needs to be done in this area as there are aspects that are yet to be explored. The findings of this research serve to add to the literature on knowledge sharing focussing on non-academic staff of higher learning institutions.
\end{abstract}

Keywords: Trust; Perceived risk; Knowledge sharing behaviour; Nonacademic staff; Higher learning institutions

Biographical notes: Dr. Muhammad Sabbir Rahman is an Associate Professor at Department of Marketing and International Business, North South University (NSU), Bangladesh. He obtained his PhD from Department of Business Administration, International Islamic University Malaysia. During the tenure of 
his $\mathrm{PhD}$ and teaching career in different Universities he has demonstrated excellent research and teaching skill, worked under various projects which were supervised by top researchers from various Universities. In the meantime, he has already published over 105 articles in different international journals and presented 30 proceedings at home and abroad. Until now he has appointed as an editorial member of 20 journal local and international and member of 7 top associations in his fields. His research focuses are on marketing segmentation, service quality, climate change, health care marketing, tourism marketing, and knowledge management.

Dr. Nuraihan Mat Daud currently is a Professor and Dean of Kulliyyah of Languages and Management (KLM) in International Islamic University Malaysia (IIUM). She has been involved in multiple disciplinary researches in the areas of languages and technology-enhanced learning, problem solving and learning, knowledge management, adult learning.

Dr. Murali Raman currently is a Professor and Dean of Faculty of Management (FOM) in Multimedia University, Malaysia. He has been involved in multiple disciplinary researches in the areas of waste management, information technology management, knowledge management and human performance.

\section{Introduction}

The practice of knowledge sharing in an organization is an important element in the process of knowledge management (Nonaka \& Takeuchi, 1995; Titi Amayah, 2013; Shih, Nuutinen Hwang, \& Chen, 2010). Bartol and Srivastava (2002) defined knowledge sharing as the individual staff's intention to share relevant information, recommendation, and relevant expertise with other staff in attaining the goal of the task. However, there is a tendency for some staff to regard their professional and expert skill as their personal assets to stay competitive in their respective position (Budiardjo, Pamenan, Hidayanto, Meyliana, \& Cofriyanti, 2017; Khadir-Poggi \& Keating, 2015; Lam \& Lambermont-Ford, 2010; Titi Amayah, 2013). As a consequence, effective sharing of knowledge among staff fails to take place (Martelli, Bellini, \& Salvatori, 2015; Fisher \& Fisher, 1998).

One of the ways of getting the staff to share their knowledge is by gaining their trust. This is supported by a number of researches in this area. Researchers have found that there is a significant relationship between trust and staff willingness to share knowledge among themselves (Visser, 2010; Ho, Kuo, \& Lin, 2012; Wickramasinghe \& Widyaratne, 2012; Casimir, Lee, \& Loon, 2012). Researchers like Renzl (2008) and Kuo (2013) highlighted the importance of trust in the work environment in order to foster employee's willingness to share knowledge. Apart from that, researchers also agreed that trust can be more efficient if the perceived risk is low among them (Wickramasinghe \& Widyaratne, 2012; Cook \& Wall, 1980). Therefore, in this research, it is interesting to explore the extent of relationship between trust and knowledge sharing behaviour where perceived risk plays as a mediating role in the relationship (McAllister, 1995; Casimir et al., 2012; Kuo, 2013).

\section{Backgrounds to the study}

This research was conducted in Malaysia where the number of higher learning institutions grew in a remarkable manner. To date, twenty public universities and 
approximately 600 private higher learning institutions, including eleven private universities have been established in Malaysia (Arokiasamy \& Nagappan, 2012). This calls for a large number of employees under various categories which include managers, directors, assistant managers, clerks and technicians. They are important in ensuring that the daily operations of the institution run smoothly. In order to satisfy the stakeholders and to have an edge over other institutions, it is important that both the executive and non-executive employers share their knowledge.

Thus, this research aims to investigate the extent to which trust influences knowledge sharing behaviour among non-academic staff of higher learning institutions (Executive and Non-Executive levels) when perceived risk plays as a mediating function. This study surveyed 250 executive and non-executive staffs from different higher learning institutions in Malaysia and intent to explore how much trust influences staff's knowledge sharing behaviour where perceived risk plays as a mediating role between these relationships. In order to benefit from knowledge sharing practises, it is important for the organization to understand how trust influences staff's knowledge sharing behaviour. This research will focus on this relationship and apply perceived risk as a mediating role between the relationships. In subsequent sections, the researchers will first present the overview of the importance of knowledge sharing behaviour in an organization. The constructs will be defined, and the conceptual framework formulated. The researchers will then explain the methodology adopted in this research and how data is collected, followed by model testing using structural equation modelling (SEM). Finally, this paper discussed the results and its practical implications and limitations and concluded with a few suggestions for future research.

\section{Development of conceptual framework}

Knowledge sharing in an organization can be categorized into tacit and explicit (Foos, Schum, \& Rothenberg, 2006; Herschel, Nemati, \& Steiger, 2001; Assudani, 2005; Zboralski, 2009). Previous research shows that tacit knowledge has a greater influence on knowledge sharing behaviour compared to explicit knowledge in driving the company's performance as it embodies skills, experiences, and intuition (Herschel et al., 2001; Rantaša, 2004; Koskinen, Pihlanto, \& Vanharanta, 2003; Foos et al., 2006; Islam, Kunifuji, Hayama, \& Miura, 2013). To facilitate tacit knowledge sharing in an organization, it is important to consider the degree of trust that a staff has in his/her colleagues; which has been found to have an impact on the staff's knowledge sharing behaviour (Chen, 2004). A number of research has highlighted the influence of trust on executive and non-executive staff's knowledge sharing behaviour (Herschel et al., 2001; Renzl, 2008; Chowdhury, 2005; Swift \& Hwang, 2013; Yang \& Farn, 2009; Ho, Kuo, Lin, \& Lin, 2010; Dewitte \& de Cremer, 2001; Swart \& Harvey, 2011).

Researchers define trust as the individual's staff willingness to put him/herself in a position of possible openness to someone (Dodgson, 1993; Huang \& Van de Vliert, 2006; Edelenbos \& Klijn, 2007; Azudin, Ismail, \& Taherali, 2009). In addition, Mayer, Davis, and Schoorman (1995) and Gabbay and Leenders (2003) describe trust as a set of beliefs where a trustor may assume that the trustee's activities will have positive and significant consequences for the trustor. Thus, trust can be classified in two aspects: affective and cognitive. The first one concerns emotional trust and the second is about logical trust (Ziegler \& Golbeck, 2007). Research has been done on both types of trust, and yet there are hardly any studies conducted on non-academic staff of higher learning institutions (Brashear, Boles, Bellenger, \& Brooks, 2003; Levin \& Cross, 2004; Chen, 
2004). Yang and Farn (2009), for example, explored how employees' affective-based trust influences their intention to share tacit knowledge in informal organizational settings.

Researchers have proposed that trust plays an important role in minimizing fear among staff and it ultimately enhances the intention to share knowledge (Ullah, Akhtar Shahzadi, Farooq, \& Yasmin, 2016; Renzl, 2008; He \& Wei, 2009; Yang \& Farn, 2009; Ho et al., 2010; Andrews \& Delahay, 2000). On the other hand, Gray (2001) argues that an individual's level of trust of others is highly related to the risk factors related to knowledge sharing behaviour.

Due to the threat of inequity and the possibility of others getting the credit if knowledge is shared with them, employees are reluctance to share with their colleague (McAllister, Lewicki, \& Bies, 2003). Cunningham (1967) defines perceived risk as the feeling that a staff has if the result of an act is not favourable. In summary, the literature on perceived risk describes it as a subjective assumption made by an individual that he/she may have made a mistake of trusting the wrong person (Peter \& Ryan, 1976; Sweeney, Soutar, \& Johnson, 1999). Above all, the literature has also looked into perimeters related to perceived risk which includes an individual staff's psychological, physical, financial, social, and performance risks (Jacoby \& Kaplan, 1972).

Numerous researches support that risk is related to trust, which has recently been given much attention in the social science research (Berry, 1995; Dion, Easterling, \& Miller, 1995; Doney \& Cannon, 1997; Hawes, 1994; Morgan \& Hunt, 1994; Smeltzer, 1997). Based on the above discussion, the researchers are proposing that there is a correlation between trust and an individual perceived risk where knowledge sharing behaviour is concerned (Choi, 2006; Lin, 2007; Madjar \& Ortiz-Walters, 2009). Based on the literature in this area, the following conceptual framework is proposed for further empirical examination: trust as the independent variable, perceived risk as the mediating variable and staff knowledge sharing behaviour as the dependent variable (Fig. 1).

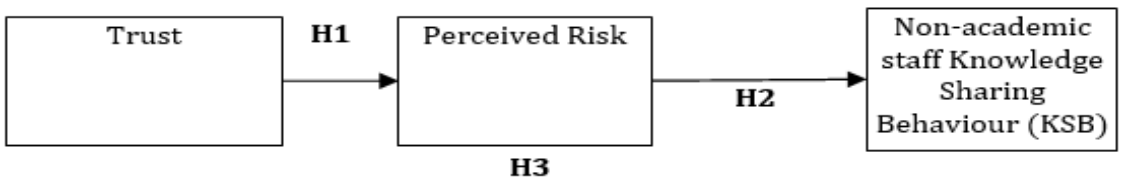

Fig. 1. Conceptual framework for knowledge sharing behaviour among non-academic staff of higher learning institutions

Based on the above framework this research proposes the following hypotheses:

Hypothesis 1 (H1): There is a significant relationship between trust at the workplace and perceived risk.

Hypothesis 2 (H2): There is a significant relationship between perceived risk and non-academic staff's knowledge sharing behaviour.

Hypothesis 3 (H3): There is a significant relationship between trust and staff's knowledge sharing behaviour when perceived risk plays as the mediation role between the two variables.

\section{Methodology}

The population of this study consists of non-academic staffs of various public and private higher learning institutions in Malaysia. This inquiry is a cross-sectional study and the 
information was collected from the Klang Valley area of the Peninsular of Malaysia (West Malaysia) and from East Malaysia (Sabah). The researchers selected those states because of the higher number of private and public higher learning institutions in those places. This research applied convenience sampling using the University intercept survey procedure. The researchers approached the respondents by making an appointment with them. Structured questionnaire surveys were distributed to the non-academic staff of the selected institutions. Apart from the respondents' demographic profile, information on trust, perceived risk and knowledge sharing behaviour were also elicited from them. Twelve items were used to measure these variables (Trust- 4items; Perceived Risk-4items and Knowledge sharing behaviour - 4items). The variable trust (T) and knowledge sharing behaviours were measured using eight items which are adapted from Swift and Hwang's (2013) research. In addition, the variable perceived risks were measured using 4 items adapted from Chen and Chang's (2013) research. This research used 5-point Likert scale ( $1=$ Strongly Disagree, $2=$ Disagree, 3= neutral, 4= Agree and 5= Strongly Agree) to allow the respondents to rate how much they agree or disagree with the statement. A total of 300 questionnaires were distributed to the targeted respondents. Out of these, only 250 respondents returned the completed questionnaire. Out of the 250 respondents, $60 \%$ of them were from the public Universities and the remaining $40 \%$ were from the private higher learning institutions. The majority of the respondents were females $(60 \%)$ and the others were males (40\%). Out of 250 respondents, $40 \%$ holds managerial position and $60 \%$ consists of the others. Most of the respondents were between 25 to 30 years old $(80 \%)$. In order to test the proposed hypotheses, this research applied two stages of data analysis. In the first stage, the researchers applied confirmatory factor analysis to confirm the constructs and test the validity and reliability of the instruments. The following section applied structural equation modeling (SEM) to test the hypotheses of the research. This research used chi-square $\left(\mathrm{X}^{2}\right)$, goodness-of-fit index (GFI), comparative fit index (CFI) and root mean square error of approximation (RMSEA) to test the fit indices of the constructs as well as the conceptual framework (Hair, Black, Babin, Anderson, \& Tatham, 2006; Fornell \& Lucker, 1981).

\section{Analyses of results and testing of hypotheses}

This research applied confirmatory factor analysis (CFA) to determine whether the constructs (i.e. Trust-T, Perceived Risk- PR and Knowledge sharing behavior- KSB) offer a good fit to the data. In addition, this research tested reliability using Cronbach alpha coefficient; construct reliability and variance extracted to compute the reliability of each construct (see Table 1). Table 2 reveals that all the items possess a good fit in favor of construct reliability and cronbach alpha coefficient (Zikmund, 2003). All the constructs are above $1.96(\mathrm{p}=0$. 05) reflecting that there is convergent validity (Anderson\& Gerbing, 1988). Based on Table 3a, 3b, it can be deduced that all constructs (three factors) have strong fit. Hence this research conceptualizes the following three factors: trusts (T), Perceived Risk (PR), and Knowledge sharing behaviour (KSB).

Table 1

Unidimensionality analysis of the Individual constructs

\begin{tabular}{cc}
\hline Factor & Comparative fit index $($ CFI) \\
\hline Trust (T) & 0.941 \\
Perceived Risk (PR) & 0.923 \\
Knowledge Sharing Behaviour (KSB) & 0.915 \\
\hline
\end{tabular}


Table 2

Construct reliability and variance extracted for each construct

\begin{tabular}{|c|c|c|c|}
\hline Variable name & $\begin{array}{l}\text { Loadings } \\
\text { (R2) }\end{array}$ & $\begin{array}{l}\text { Construct } \\
\text { Reliability } \\
\text { (above 0.7) }\end{array}$ & $\begin{array}{l}\text { Cronbach } \\
\text { Alpha } \\
\text { coefficient }\end{array}$ \\
\hline Trust (T) & & 0.703 & 0.815 \\
\hline $\begin{array}{l}\text { I have a sharing relationship with my co-workers } \\
\text { (T1) }\end{array}$ & 0.882 & & \\
\hline $\begin{array}{l}\text { My co-workers approach their jobs with } \\
\text { professionalism and dedication (T2) }\end{array}$ & 0.827 & & \\
\hline $\begin{array}{l}\text { I can talk freely to my co-workers about any } \\
\text { difficulties I am having at work (T3) }\end{array}$ & 0.863 & & \\
\hline $\begin{array}{l}\text { I can rely on my co-workers to make my job easier } \\
\text { (T4) }\end{array}$ & 0.797 & & \\
\hline Perceived Risk (PR) & & 0.709 & 0.889 \\
\hline $\begin{array}{l}\text { Possible chance of afraid and do not know what to } \\
\text { share (PR1) }\end{array}$ & 0.810 & & \\
\hline $\begin{array}{c}\text { There is a chance that knowledge sharing is not } \\
\text { work properly (PR2) }\end{array}$ & 0.827 & & \\
\hline $\begin{array}{l}\text { There is a chance that knowledge sharing will } \\
\text { negatively affect my performance (PR3) }\end{array}$ & 0.857 & & \\
\hline $\begin{array}{l}\text { There is a chance that I may get penalty of sharing } \\
\text { information with my colleagues (PR4) }\end{array}$ & 0.873 & & \\
\hline Knowledge Sharing Behaviour (KSB) & & 0.701 & 0.826 \\
\hline $\begin{array}{l}\text { I voluntarily share my knowledge with my co- } \\
\text { workers (KS1) }\end{array}$ & 0.825 & & \\
\hline $\begin{array}{l}\text { I cooperate with employees in teams or groups for } \\
\text { sharing information and knowledge (KS2) }\end{array}$ & 0.813 & & \\
\hline $\begin{array}{l}\text { I can freely access the documents, information, and } \\
\text { knowledge held by other divisions within my } \\
\text { Institutions (KS3) }\end{array}$ & 0.870 & & \\
\hline $\begin{array}{l}\text { In my department the behaviour of knowledge } \\
\text { sharing is common (KS4) }\end{array}$ & 0.841 & & \\
\hline
\end{tabular}

Table 3a

Goodness of fit indices for the measurement model

\begin{tabular}{ccc}
\hline Goodness of fit indices & Fit Criteria & Result from the Measurement Model \\
\hline$X^{2}$ & & 352.857 \\
Df & & 178 \\
$X^{2} / \mathrm{df}$ & Not more than 3 & 1.9823 \\
GFI & Closer to 1 & 0.960 \\
AGFI & Closer to 1 & 0.937 \\
CFI & Closer to 1 & 0.916 \\
RMSEA & $\leq 0.06$ & 0.053 \\
NFI & Closer to 1 & 0.921 \\
\hline
\end{tabular}

Note. Criteria adapted from Hair et al. (1995), Byrne (2001), Holmes-Smith (2001) 
Table 3b

Overall modelfit statistic

\begin{tabular}{cc}
\hline Overall Model Fit Statistic & Statistic Value \\
\hline Chisquare/Degrees of Freedom & 2.225 \\
GFI & 0.962 \\
AGFI & 0.932 \\
RMSEA & 0.006 \\
\hline
\end{tabular}

In the second step of the data analysis, the researchers applied SEM to test the hypotheses of the suggested model. The entire model proved a good fit based on the fit indices (see Table 4). The relationship between trust and perceived risk was found to be positive and significant $(\mathrm{H} 1: \mathrm{T} \rightarrow \mathrm{PR}$; $\mathrm{t}$-value $=5.62$; Path value $=0.48 * * ; \mathrm{P}$ value $=0.002)$. In addition, the relationship between perceived risk and knowledge sharing behaviour was also proven to be significant $\left(\mathrm{H} 2: \mathrm{PR} \rightarrow \mathrm{KSB}\right.$; $\mathrm{t}$ value $=6$. 72; Path value $=0.35^{* *}$; $\mathrm{p}$ value $=0$. 017). Based the Cohen's (1988) rules, both the relationships proved to be significant. Thus, this research accepted hypotheses one and two. To test the mediation impact of perceived risk between trust and knowledge sharing behaviours, this research applied Baron and Kenny's (1986) logic where the direct effect of trust (T) on knowledge sharing behaviour was first tested. The relationship between the path was found to be significant $\left(\mathrm{R}^{2}=0.57\right)$. After introducing the mediating variables (i.e., Perceived risk), the path between trust and knowledge sharing behaviours became insignificant which reflects that perceived risk plays the mediating role $\left(\mathrm{R}^{2}=0.70\right)$. This research serves to confirm that trust and knowledge sharing behaviour have a significant relationship when perceived risk plays a strong mediation role between the two. Hence hypothesis 3 is accepted.

Table 4

Model-fit indices for structural models

\begin{tabular}{ccc}
\hline $\begin{array}{c}\text { Model-fit Indices } \\
\text { Chi-square/df }\end{array}$ & $\begin{array}{c}\text { Results } \\
\mathbf{2 . 7 0}\end{array}$ & $\begin{array}{c}\text { Recommended Value } \\
\leq \mathbf{3}\end{array}$ \\
\hline GFI & 0.935 & Close to 1 \\
AGFI & 0.907 & Close to 1 \\
NFI & 0.867 & Close to 1 \\
CFI & 0.923 & Close to 1 \\
RMSEA & 0.059 & $\leq 0.06$ \\
\hline
\end{tabular}

Note. Criteria adapted from Hair et al. (1995), Byrne (2001), Holmes-Smith (2001)

\section{Conclusion and managerial implications}

The results of this research imply that the knowledge sharing behaviour of non-academic staff of higher learning institutions is influenced by the extent of trust that they have in their fellow colleagues. Based on the empirical examination, the findings also revealed that workplace trust is a stronger influencing on knowledge sharing behaviour when perceived risk factors play a mediating role between the relationship. This finding implies 
that individual non-academic staffs of higher learning institutions are more willing to share knowledge when the level of perceived risk is minimal. With this knowledge, there is a need for the managers to be proactive and reactive to enhance the trust and confidence level in order to reduce staff's fear of knowledge sharing (Durst, Edvardsson, \& Bruns, 2015; Chong \& Besharati, 2014; Renzl, 2008; Tong \& Mitra, 2009; Yang \& Farn, 2009). It is important for them to build trust at the workplace to promote knowledge sharing at every level of the hierarchy and at various departments within the institutions. In order to assist the employees to overcome their perceived risk, it is recommended that managers and policy makers of a higher learning institution introduce training programmes and a reward system that rewards those who were willing to share their knowledge that can improve the standing of the institution. In summary, the researchers recommend that managers facilitate group-binding programmes to encourage a closer tie among the staff. This may lead to a knowledge sharing practice among the staff and the various units in the institutions. To summarize, this research contributes to the empirical study on knowledge management in general and trust, perceived risk and knowledge sharing in particular in the context of non-academic staff of higher learning institutions.

\section{Limitation and suggestions for future research}

Previous empirical research suggested that many variables can influence knowledge sharing behaviour. However, in this study, the researchers focused only on three variables and established a direct and indirect relationship among the constructs. Yet factors such as sex, education, race and generation may also act as a moderator between perceived risk and knowledge sharing behaviour. However, they were not examined due to the limited scope of this study. The data was collected only from universities in Malaysia and it may not be representative of non-academic staff of higher institutions of learning in other countries. Future research may include a bigger sample looking at the various respondents' demographic information. The above-mentioned limitations may inspire other scholars to conduct further empirical research in this area and encourage the management of higher learning institutions to take the necessary initiatives to promote knowledge sharing behaviour among their non-academic staff.

\section{References}

Anderson, J. C., \& Gerbing, W. D. (1988). Structural equation modelling in practice: A review and recommended two stage approach. Psychological Bulletin, 103(3), 411423.

Andrews, K. M., \& Delahay, B. L. (2000). Influences on knowledge processes in organizational learning: The psychosocial filter. Journal Management Studies, 37(6), 797-810.

Arokiasamy, A. R. A., \& Nagappan, K. (2012). An analysis of globalization and higher education in Malaysia. Business Intelligence Journal, 5(1), 141-150.

Assudani, R. H. (2005). Catching the chameleon: Understanding the elusive term "knowledge". Journal of Knowledge Management, 9(2), 31-44.

Azudin, N., Ismail, M. N., \& Taherali, Z. (2009). Knowledge sharing among workers: A study on their contribution through informal communication in Cyberjaya, Malaysia. Knowledge Management \& E-Learning (KM\&EL), 1(2), 139-162.

Baron, R. M., \& Kenny, D. A. (1986). The moderator-mediator variable distinction in social psychological research: Conceptual, strategic, and statistical considerations. Journal of Personality and Social Psychology, 51(6), 1173-1182. 
Bartol, K. M., \& Srivastava, A. (2002). Encouraging knowledge sharing: The role of organizational reward systems. Journal of Leadership and Organization Studies, 9(1), 64-76.

Berry, L. L. (1995). Relationship marketing of services - Growing interest, emerging perspectives. Journal of the Academy of Marketing Science, 23(4), 236-245.

Brashear, T. G., Boles, J. S., Bellenger, D. N., \& Brooks, C. M. (2003). An empirical test of trust-building processes and outcomes in sales manager-salesperson relationships. Journal of the Academy of Marketing Science, 31(2), 189-200.

Budiardjo, E. K., Pamenan, G., Hidayanto, A. N., Meyliana, \& Cofriyanti, E. (2017). The impact of knowledge management system quality on the usage continuity and recommendation intention. Knowledge Management \& E-Learning (KM\&EL), 9(2), 200-224.

Byrne, B. M. (2001). Structural equation modeling with AMOS: Basic concepts, applications, and programming. Mahwah, NJ. Lawrence Erlbaum Associate.

Casimir, G., Lee, K., \& Loon, M. (2012). Knowledge sharing: Influences of trust, commitment and cost. Journal of Knowledge Management, 16(5), 740-753.

Chen, C.-J. (2004). The effect of knowledge attribute, alliance characteristics, and absorptive capacity on knowledge transfer performance. $R \&$ D Management, 34(3), 311-321.

Chen, Y. S., \& Chang, C. H. (2013). Towards green trust: The influences of green perceived quality, green perceived risk, and green satisfaction. Management Decision, $51(1), 63-82$.

Choi, J. N. (2006). Multilevel and cross-level effects of workplace attitudes and group member relations on interpersonal helping behaviour. Human Performance, 19(4), 383-402.

Chong, C. W., \& Besharati, J. (2014). Challenges of knowledge sharing in the petrochemical industry. Knowledge Management \& E-Learning (KM\&EL), 6(2), 171187.

Chowdhury, S. (2005). The role of affect-and cognition-based trust in complex knowledge sharing. Journal of Managerial Issues, 17(3), 310-326.

Cohen, J. (1988). Statistical power analysis for the behavioural sciences (2nd ed.). Hillsdale, NJ: Lawrence Erlbaum.

Cook, J., \& Wall, T. (1980). New work attitude measures of trust, organizational commitment and personal need non-fulfillment. Journal of Occupational and Organizational Psychology, 53(1), 39-52.

Cunningham, S. M. (1967). The major dimensions of perceived risk. In D. F. Cox (Ed.), Risk Taking and Information Handling in Consumer Behavior (pp. 82-108). Boston, MA: Harvard University Press.

Dewitte, S., \& de Cremer, D. (2001). Self-control and cooperation: Different concepts, similar decisions? A question of the right perspective. The Journal of Psychology, 135(2), 133-153.

Dion, P., Easterling, D., \& Miller, S. J. (1995). What is really necessary in successful buyer/seller relationships? Industrial Marketing Management, 24(1), 1-9.

Dodgson, M. (1993). Learning, trust, and technological collaboration. Human Relations, 46(1), 77-95.

Doney, P. M., \& Cannon, J. P. (1997). An examination of the nature of trust in buyerseller relationships. Journal of Marketing, 61(2), 35-51.

Durst, S., Edvardsson, I. R., \& Bruns, G. (2015). Sustainable organisations and knowledge process outsourcing: conditions for success. International Journal of Knowledge and Learning, 10(2), 110-123.

Edelenbos, J., \& Klijn, E. H. (2007). Trust in complex decision-making networks: A 
theoretical and empirical exploration. Administration \& Society, 39(1), 25-50.

Fisher, K., \& Fisher, M. D. (1998). The distributed mind: Achieving high performance through the collective intelligence of knowledge work teams. New York, NY: AMACON.

Foos, T., Schum, G., \& Rothenberg, S. (2006). Tacit knowledge transfer and the knowledge disconnect. Journal of Knowledge Management, 10(1), 6-18.

Fornell, C., \& Larcker, D. F. (1981). Evaluating structural equation models with unobservable variables and measurement error. Journal of Marketing Research, 18(1), 39-50.

Gabbay, S. M., \& Leenders, R. T. A. J. (2003). Creating trust through narrative strategy. Rationality \& Society, 15(4), 509-539.

Gray, P. H. (2001). The impact of knowledge repositories on power and control in the workplace. Information Technology \& People, 14(4), 368-384.

Hair, J. F., Anderson, R., Tatham, R., \& Black, W. (1995). Multivariate data analysis with readings. Englewood Cliffs, NJ: Prentice-Hall International.

Hair, J. F., Black, W. C., Babin, B. J., Anderson, R. E., \& Tatham, R. L. (2006). Multivariate data analysis (6th ed). Uppersaddle River, NJ: Pearson Prentice Hall.

Hawes, J. (1994). To know me is to trust me. Industrial Marketing Management, 23(3), 215-219.

He, W., \& Wei, K. K. (2009). What drives continued knowledge sharing? An investigation of knowledge-contribution and-seeking beliefs. Decision support systems, 46(4), 826-838.

Herschel, R. T., Nemati, H., \& Steiger, D. (2001). Tacit to explicit knowledge conversion: Knowledge exchange protocols. Journal of Knowledge Management, 5(1), 107-116.

Ho, L.-A., Kuo, T.-H., \& Lin, B. (2012). How social identification and trust influence organizational online knowledge sharing. Internet Research, 22(1), 4-28.

Ho, L.-A., Kuo, T.-H., Lin, C., \& Lin, B. (2010). The mediate effect of trust on organizational online knowledge sharing: an empirical study. International Journal of Information Technology \& Decision Making, 9(4), 625-644.

Holmes-Smith, P. (2001). Introduction to structural equation modelling using LISREAL. Perth: ACSPRI-Winter Training Program.

Huang, X., \& Van de Vliert, E. (2006). Job formalization and cultural individualism as barriers to trust in management. International Journal of Cross Cultural Management, $6(2), 221-242$.

Islam, M. S., Kunifuji, S., Hayama, T., \& Miura, M. (2013). Knowledge sharing practices among doctoral students in JAIST to enhance research skills. Knowledge Management \& E-Learning (KM\&EL), 5(2), 170-185.

Jacoby, J., \& Kaplan, L. B. (1972). The components of perceived risk. In Proceedings of the Third Annual Conference, Association for Consumer Research (pp. 382-393).

Khadir-Poggi, Y., \& Keating, M. (2015). Intellectual capital, knowledge management, knowledge economies and innovation: The case of small asset management firms in Ireland. International Journal of Knowledge and Learning, 10(2), 147-163.

Koskinen, K. U., Pihlanto, P., \& Vanharanta, H. (2003). Tacit knowledge acquisition and sharing in a project work context. International Journal of Project Management, 21(4), 281-290.

Kuo, T. H. (2013). How expected benefit and trust influence knowledge sharing. Industrial Management \& Data Systems, 113(4), 506-522.

Lam, A., \& Lambermont-Ford, J.-P. (2010). Knowledge sharing in organisational contexts: A motivation-based perspective. Journal of Knowledge Management, 14(1), $51-66$.

Levin, D. Z., \& Cross, R. (2004). The strength of weak ties you can trust: the mediating role of trust in effective knowledge transfer. Management Science, 50(11), 1477-1490. 
Lin, C. P. (2007). To share or not to share: modeling tacit knowledge sharing, its mediators and antecedents. Journal of Business Ethics, 70(4), 411-428.

Madjar, N., \& Ortiz-Walters, R. (2009). Trust in supervisors and trust in customers: Their independent, relative, and joint effects on employee performance and creativity. Human Performance, 22(2), 128-142.

Martelli, C., Bellini, E., \& Salvatori, M. F. (2015). Knowledge management and reuse in tourism destination observatories. International Journal of Knowledge and Learning, 10(1), 1-15.

Mayer, R. C., Davis, J. H., \& Schoorman, F. D. (1995). An integrative model of organizational trust. Academy of Management Review, 20(3), 709-734.

McAllister, D. J. (1995). Affect and cognition-based trust as foundations for interpersonal cooperation in organizations. Academy of Management Journal, 38(1), 24-59.

McAllister, D. J., Lewicki, R. J., \& Bies, R. J. (2003). Hardball: How trust and distrust interact to predict hard influence tactic use. Unpublished paper, Georgetown, Washington, DC, USA.

Morgan, R. M., \& Hunt, S. D. (1994). The commitment-trust theory of relationship marketing. Journal of Marketing, 58(3), 20-38.

Nonaka, I., \& Takeuchi, H. (1995). The knowledge-creating company: How Japanese companies create the dynamics of innovation. New York, NY: Oxford University Press.

Peter, J. P., \& Ryan, M. J. (1976). An investigation of perceived risk at the brand level. Journal of Marketing Research, 13(2), 184-189.

Rantaša, K. S. (2004). The importance of tacit knowledge for sustaining a competitive advantage. Our Economy (Nase Gospodarstvo), 50(3/4), 24-30.

Renzl, B. (2008). Trust in management and knowledge sharing: the mediating effects of fear and knowledge documentation. Omega, 36(2), 206-220.

Shih, J. L., Nuutinen, J., Hwang, G. J., \& Chen, N. S. (2010). Building virtual collaborative research community using knowledge management approach. Knowledge Management \& E-Learning (KM\&EL), 2(3), 293-311.

Smeltzer, L. R. (1997). The meaning and origin of trust in buyer-supplier relationships. Journal of Supply Chain Management, 33(4), 40-48.

Swart, J., \& Harvey, P. (2011). Identifying knowledge boundaries: The case of networked projects. Journal of Knowledge Management, 15(5), 703-721.

Sweeney, J. C., Soutar, G. N., \& Johnson, L. W. (1999). The role of perceived risk in the quality-value relationship: a study in a retail environment. Journal of Retailing, 75(1), $77-105$.

Swift, P. E., \& Hwang, A. (2013). The impact of affective and cognitive trust on knowledge sharing and organizational learning. The Learning Organization, 20(1), 20-37.

Titi Amayah, A. (2013). Determinants of knowledge sharing in a public sector organization. Journal of Knowledge Management, 17(3), 454-471.

Tong, J., \& Mitra, A. (2009). Chinese cultural influences on knowledge management practice. Journal of Knowledge Management, 13(2), 49-62.

Ullah, I., Akhtar, K. M., Shahzadi, I., Farooq, M., \& Yasmin, R. (2016). Encouraging knowledge sharing behavior through team innovation climate, altruistic intention and organizational culture. Knowledge Management \& E-Learning (KM\&EL), 8(4), 628645.

Visser, M. (2010). Constructing organisational learning and knowledge socially: An interactional perspective. International Journal of Knowledge and Learning, 6(4), 285-294.

Wickramasinghe, V., \& Widyaratne, R. (2012). Effects of interpersonal trust, team leader 
support, rewards, and knowledge sharing mechanisms on knowledge sharing in project teams. VINE, 42(2), 214-236.

Yang, S. C., \& Farn, C. K. (2009). Social capital, behavioural control, and tacit knowledge sharing - A multi-informant design. International Journal of Information Management, 29(3), 210-218.

Zboralski, K. (2009). Antecedents of knowledge sharing in communities of practice. Journal of Knowledge Management, 13(3), 90-101.

Ziegler, C.-N., \& Lausen, G. (2005). Propagation models for trust and distrust in social networks. Information Systems Frontiers, 7(4/5), 337-358.

Zikmund, W. G. (2003). Business research methods (7th ed.). Mason, OH: Thomson/South-Western. 